\title{
Initiatives of Urban Agriculture in Semarang City: Pathways for Sustainability
}

\author{
Zahra Nur Hasanah ${ }^{1, *}$, Wiwandari Handayani ${ }^{1}$, and Nana Kariada Tri Martuti ${ }^{2}$ \\ ${ }^{1}$ Department of Urban and Regional Planning, Diponegoro University, 50277, Semarang, Indonesia \\ ${ }^{2}$ Department of Biology, Semarang State University, 50229, Semarang, Indonesia
}

\begin{abstract}
Urban agriculture (UA) has become a popular concept to bridge growth of urban areas with adequate provision of agricultural land, cheap and healthy food. UA in Semarang began to be encouraged by Semarang City Government since 2015 and involves family welfare groups for its implementation. Most of the people involved in UA activities are often based on hobbies whereas some of them start reaching out to businesses. This study aims to elaborate the initiatives from government, community/individual, university, and corporation to promote UA in Semarang. The methods were conducted by using interactive analysis model which is presented by Miles, Huberman, and Saldaña. By elaborate the initiatives of urban agriculture in Semarang, the study shows that initiatives from communities/individual are more promising to promote sustainability rather than initiatives which comes from the government. The major difference among initiatives is due to community eagerness to do UA activities if it comes from their interests and desires, whereas initiatives from the government are more likely to encourage community participation and as part of social innovation.
\end{abstract}

\section{Introduction}

Over the last few years, urban agriculture (UA) is increasingly being promoted as a strategy for enhancing urban food security as well as urban climate change adaptation and mitigation [1]. UA is promoted to realize the sustainable urban development through optimizing a limited vacant land/yard for the agriculture activities. As part of the mitigation and adaptation to food shortages, the implementation of urban agriculture also generates cobenefits on people's livelihoods in both social, economic, and environmental aspects. For example, UA is capable of providing the urban greenery, healthy open space, and food security. Although UA will never replace or compensate for rural agriculture, UA could be seen as a livelihood that enhances food security, nutritional health, and creates employment [2]. UA also provide a cheap and flexible solution for people who are experience financial difficulties [3]. However, the potential of UA to play a pivotal role in urban poverty and reducing food insecurity should not be overemphasized since its share in overall agricultural revenues and production is often very limited [4].

\footnotetext{
* Corresponding author: zahranurhasanah@pwk.undip.ac.id
} 
Semarang has begun implementing UA initiatives since 2015. Implementation of UA is one of the strategies to promote UA for enhancing food security mentioned in Semarang City Resilience Strategy [5]. UA was designed to be developed in densely populated urban areas through yard optimization program by the agricultural agency (Dinas Pertanian) of Semarang. Activities of UA become important for urban farmers because the farmers in UA are food producers and at the same time also the consumer [6].

UA will continue to become a significant contributor to urban communities and decline the difference between rural and urban agriculture [7]. Considering the importance of UA, the agricultural agency has encouraged a community to establish the group who play an important role in UA in Semarang. The groups are under existing institutional mechanisms, such as farmer associations (Kelompok Tani/KT) and women's farm associations (Kelompok Wanita Tani/KWT). Other than groups formed by the agricultural agency, apparently enthusiasts of urban agriculture activities also come from homemakers who do agriculture activities because of their hobby.

The urban farmers in Semarang have adversity in maintaining production even more for marketing. The adversity occurs because lack of capacity especially accesses to information, technology, and markets. The challenges also occur because the communities are only enthusiastic in the beginning, then their enthusiasm gradually disappeared. However, there is the amount of group who continue to implement the UA activities. Due to many programs and initiatives to promote UA in Semarang, this study aims to elaborate the initiatives from government, community/individual, university, and corporation to promote UA in Semarang.

\section{Data and Methods}

\subsection{Data needs}

The data used in this study were based on the urban agriculture baseline in Semarang City and information that explained how urban agriculture was initiated in Semarang. These data were obtained from interview to key informants who were involved in UA activities and literature review from the documents of agricultural and food security agency. Interview and literature review as a data collection method aims to validate data by collecting data and information from different peoples and sources. Key informants are determined by using purposive sampling. A semi-structured interview was conducted to gather information from respondents to comprehend the initiatives of urban agriculture in Semarang. The list of key informants in this study is shown in Table 1.

Table 1. Key Informant

\begin{tabular}{|c|l|l|}
\hline No. & \multicolumn{1}{|c|}{ Key Informants } \\
\hline 1. & City Government & $\begin{array}{l}\text { Agricultural Agency of Semarang City } \\
\text { Food Security Agency Semarang City Kota Semarang } \\
\text { Regional Planning and Development Board (BAPPEDA) } \\
\text { of Semarang City }\end{array}$ \\
\hline 2. & $\begin{array}{l}\text { Community/Urban } \\
\text { Farmers }\end{array}$ & $\begin{array}{l}\text { KWT Pandean Lamper, KT Barusari, KWT Purwosari, } \\
\text { Griya KetelaQ, KWT Plalangan, KT Livestock Tandang, } \\
\text { and Crispy Farm. }\end{array}$ \\
\hline
\end{tabular}

\subsection{Methods}

The analysis methods were conducted by using interactive analysis model which is presented by Miles, Huberman, and Saldaña [8]. The phases of research were done based 
on the interactive analysis model which consist of data collection, data condensation, data display, and conclusion [8]. Data collection is conducted by compiling a list of question for an interview, data needs, and literature review. Data condensation (reduction) is made to determine the relevant data and to focus the data that leads to answer research questions. Data condensation is made to simplify and summarize systematically and explain important points about the findings and their meaning. In the process of data condensation, only data findings related to research problems will be used, while for data that has nothing to do with the research problem will be discarded. Furthermore, the data display can be done in the form of narratives, pictures, tables, and graphs. The purpose of data display is primarily to combine information so that it can provide a general description of the situation. Data display in the interactive analysis model is part of data analysis. Conclusions are drawn up during the research process, such as the data condensation process, if the data collected is sufficient then a temporary conclusion will be obtained, and after the data display is taken, the conclusions can be drawn. Figure 1 shows the phase of analysis interactive model.

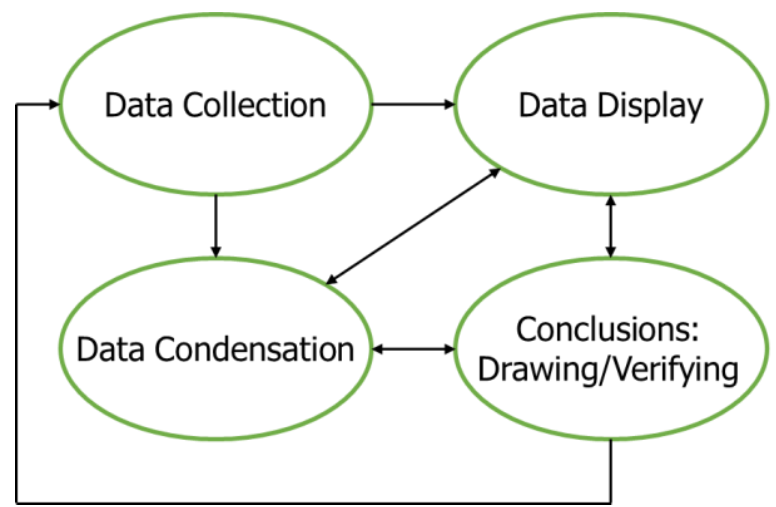

Source: Miles, Huberman, and Saldaña, 2014

Fig 1. Analysis Interactive Model

\section{Result and Discussion}

\subsection{Result}

An initiative of UA in Semarang can be differentiated by the initiatives from government, individual/community, university, and corporation.

\subsubsection{Initiatives from Government of Semarang City}

UA is promoted to enhance food security and as a global commitment to realize sustainable development goals. In the context of Semarang, it is accommodated in the medium-term development plan which aims to strengthen the people's economy based on local excellence.

In Semarang City, the implementation of UA activities appears in different forms, initiators, and spatial structures, which can be expressed by hydroponics, aquaponics, greenhouses, community gardens, and school farms. This diversity is the results of the policy by the city government to realize urban agriculture in Semarang. Since 2015, Semarang City Government has issued many policies to boost the implementation of urban agriculture. Several initiatives were undertaken to support UA in Semarang, mostly 
initiated by the agricultural agency and food security agency. Table 2 shows the initiatives by the agencies.

Table 2. Initiatives for UA Activities in Semarang

\begin{tabular}{|c|c|c|}
\hline Initiators & Program Initiatives & Program Description \\
\hline $\begin{array}{l}\text { Semarang City } \\
\text { Government }\end{array}$ & Thematic Kampong & $\begin{array}{l}\text { Thematic Kampong started in mid- } \\
2016 \text {, aimed to overcome poverty, } \\
\text { especially the problems of basic } \\
\text { needs fulfillment, to encourage } \\
\text { local economy by exploring the } \\
\text { economic potential of the } \\
\text { community as a stimulus for } \\
\text { regional development, as well as } \\
\text { improving the quality of the } \\
\text { environment }\end{array}$ \\
\hline Agricultural Agency & $\begin{array}{l}\text { 1. The yard optimization } \\
\text { (Pemanfaatan Tanah } \\
\text { Pekarangan) } \\
\text { 2. Establishment of farmer } \\
\text { associations (KT) and } \\
\text { women's farm associations } \\
\text { (KWT) which represented by } \\
\text { each district in Semarang } \\
\text { (embedded in family welfare } \\
\text { groups) }\end{array}$ & $\begin{array}{l}\text { 1. Utilize the yard for planting } \\
\text { vegetable crops to reduce the } \\
\text { dependence on the market } \\
\text { 2. The group will become the } \\
\text { main role to promote urban } \\
\text { agriculture in Semarang. }\end{array}$ \\
\hline $\begin{array}{l}\text { Food Security } \\
\text { Agency }\end{array}$ & $\begin{array}{l}\text { Development of Sustainable Food } \\
\text { House (Pengembangan Kawasan } \\
\text { Rumah Pangan Lestari/KRPL) }\end{array}$ & $\begin{array}{l}\text { To maintain the sustainability of } \\
\text { urban agriculture through crop } \\
\text { breeding programs, ensuring food } \\
\text { supply and demand }\end{array}$ \\
\hline
\end{tabular}

Some of these policies have made diversity in the implementation of UA in Semarang. However, several places get each program from three agencies. By the type of program which has similarities, it is difficult for the community to implement the program simultaneously. Several programs are also applied to communities without considering their social, economic, and environmental conditions. For example, the Hydroponic Thematic Kampong which is established in Tanjung Mas sub-district in 2016 did not go well. It was due to misalignment of the implementation process, concept planning and kampong themes that are not on target, and low community support [9].

As for the other program initiatives such as yard optimization and the establishment of KT and KWT, the 16 districts that had been initiated by the agricultural agency indicated the sustainability of the program. The program undertaken by the agricultural agency is anticipation for declining agricultural productivity in Semarang which requires the handling and innovation of each concerned agency.

Some KWTs and KTs who received initiation from the government managed to continue the program and expanded the program not only to plant vegetable crops but also started to seed and harvesting. KWT Purwosari accomplished the program in developing the benefits of the yard optimization program. The harvesting who were managed by KWT Purwosari can be seen in Figure 2 and Figure 3. 

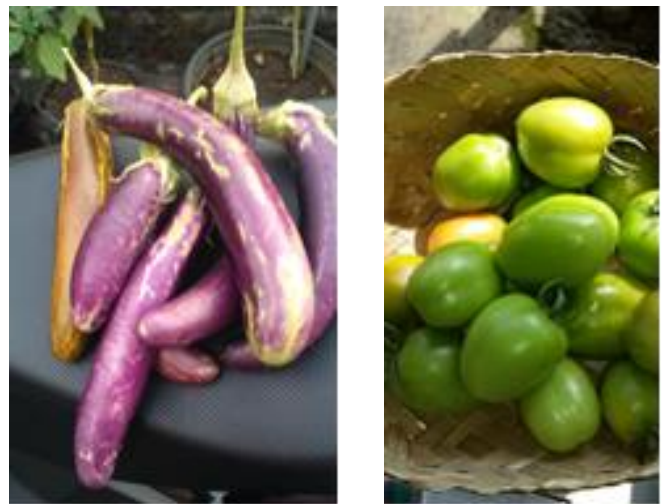

Source: KWT Purwasari’s Documentation, 2018

Fig 2. Harvest of KWT Purwasari

However, KWTs and KTs experience constraints in UA activities. Some of these constraints are dependence on the government as the first initiator, depending on the group leader in the implementation of the UA, and lack of local champion within the community groups who intend to continue UA. Another obstacle is lack of access to technology, especially the use of hydroponics as a planting medium. Many hydroponics is not running, because people do not know how to operate them.
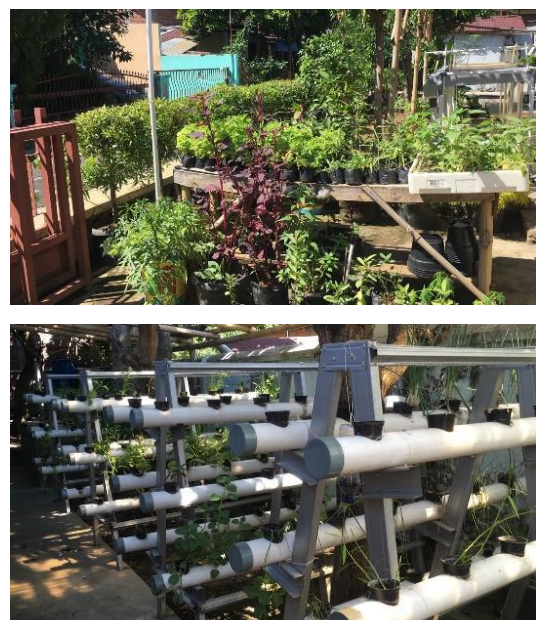
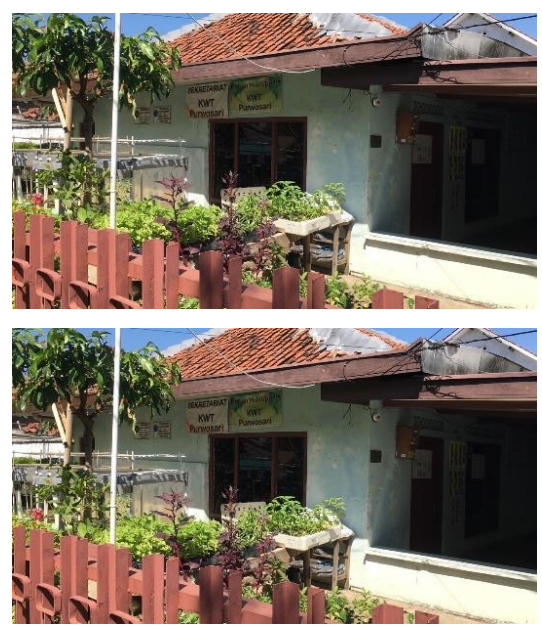

Fig 3. Yard Optimization Program by KWT Purwosari

Development of Sustainable Food House Area (KRPL) is one of the programs by the Food Security Agency of Semarang City. KRPL is a concept of food house built in a settlement area, which is developed to fulfill the food and nutrition needs of the family, as well as can be a way to increase income.

A total of 69 out of 177 sub-districts in Semarang have received funding for the KRPL program. This amount only covers $38.9 \%$ of total districts in Semarang City. However, from its distribution, each district has been represented by several sub-districts who have received funding for the KRPL program. One example from UA activities conducted by the Food Security Agency of Semarang at the Livestock Farmer Group Tandang sub-district, which can be seen in Figure 4. 

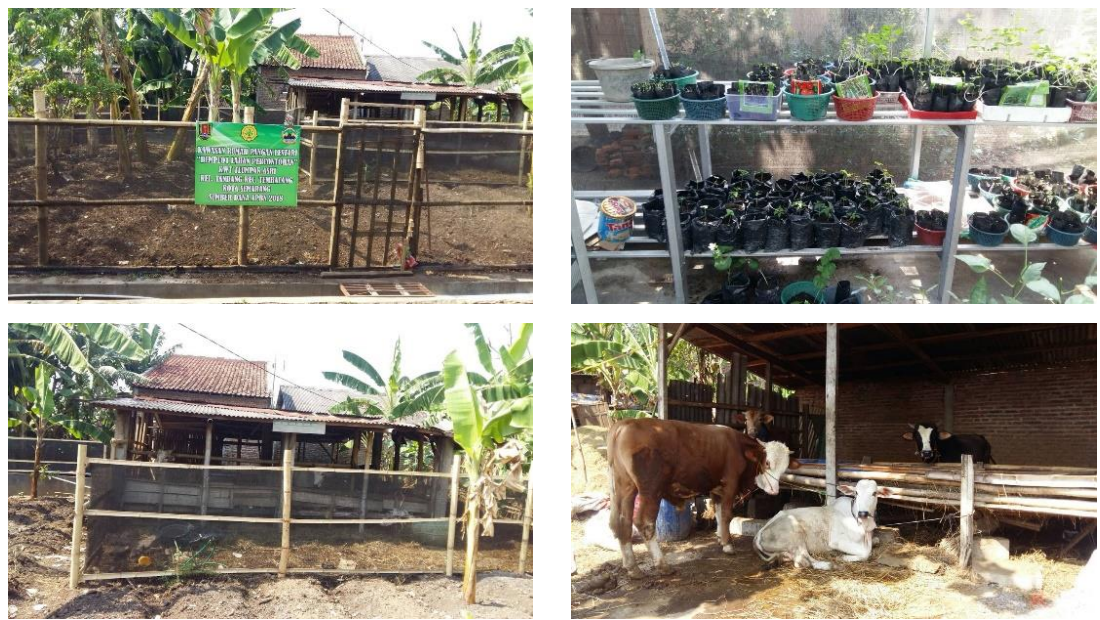

Fig 4. KRPL Program by Tandang Livestock Farmer Group

\subsubsection{Initiatives from Individual, Communities, University, and Corporation}

One of the biggest challenge faced by UA activities, especially urban farmers, is access to land. Although many UA programs are located on vacant land, their long-term sustainability often depends on land availability. Nevertheless, Semarang as a city has its uniqueness regarding land availability. Although within 25 years (1990-2015) Semarang has increased the number of built up area by $31 \%$ [10], some areas in Semarang City such as Gunung Pati and Mijen still have access to land that can be utilized for agriculture.

The availability of the land is widely used by individuals/communities who want to do UA activities. For example, Crispy Farm Corporation which is located in Gedawang subdistricts, Banyumanik. Crispy Farm was first developed by a housewife whose hobby is planting crops. By utilizing a land of $500 \mathrm{~m}^{2}$ and using a greenhouse with hydroponics as a planting medium, the owner managed to expand her crop production to sell to many supermarkets in Semarang, Solo, Magelang, and Yogyakarta. Crispy Farm's sold commodities are vegetables and fruits, such as lettuce, tomatoes, and melons. The commodity is selected, due to the high selling value and more easily produced. Figure 5 shows the activities in Crispy Farm.
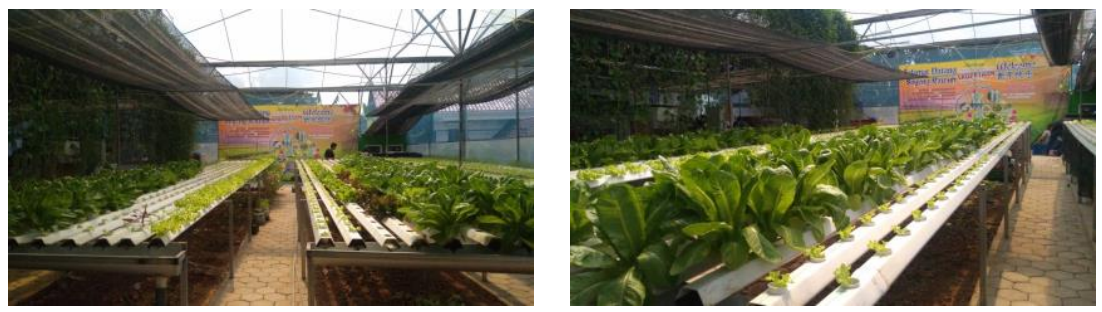

Fig 5. Individual Initiatives on Urban Agriculture by Crispy Farm

Initiatives from University and Corporation managed in the form of community empowerment by the university and Corporate Social Responsibilities (CSR). For example, Pesantren Sunan Gunung Jati Al Ba'alawy which is located in Gunung Pati district get an assist from Institut Pertanian Bogor (IPB) and Universitas Negeri Semarang (UNNES) to 
form Agrofarm who are involved in agriculture and livestock. Pesantren Sunan Gunung Jati Al Ba'alawy also established Agriculture Vocational High School with the aim to support all urban agricultural activities in the pesantren. Moreover, pesantren also get CSR from Indonesia Power to do aquaponics. However, the most generated production remains from plantation land. According to pesantren officer, hydroponics and aquaponics as a planting medium are not significantly used in Gunung Pati, because the land is still considerable. Aquaponic and hydroponics are more suitable in urban areas where the land is narrow.

The pesantren has succeeded in harvesting and selling its harvest to the market every morning by pesantren students. One of the most popular crops is Walindo (Waluh Indonesia/Indonesian Pumpkins). The pesantren also sells many vegetable crops such as lettuce, celery, tomatoes, and eggplant. The type of urban agriculture which is managed in pesantren diverse from aquaponic, hydroponic, or planting in terraces. The activities of UA in Pesantren Sunan Gunung Jati Al Ba'alawy can be seen in Figure 6.
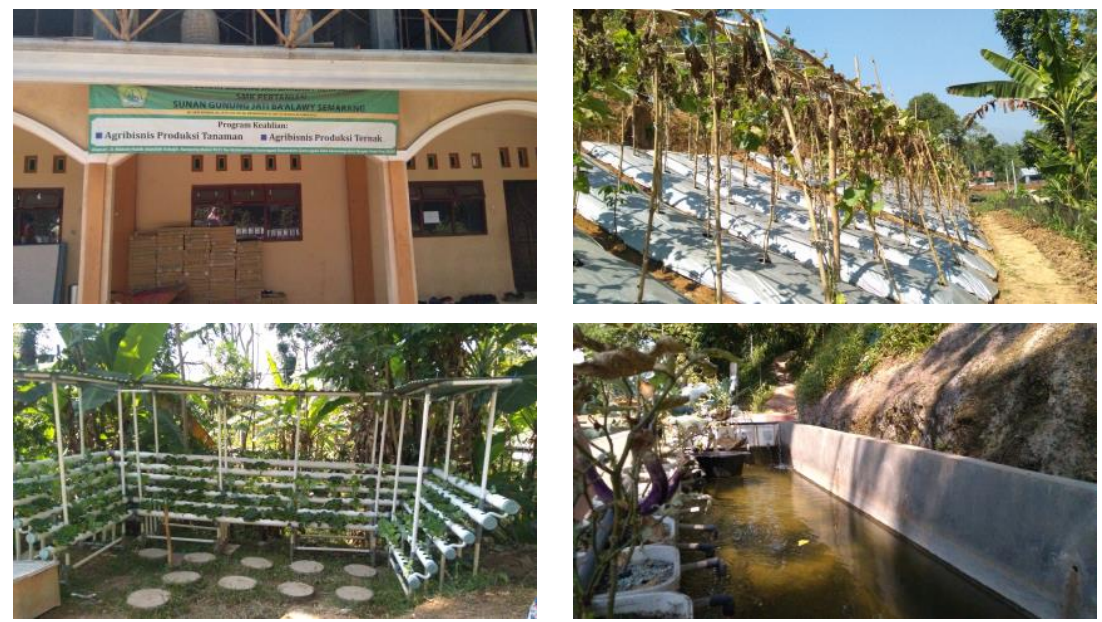

Fig 6. Initiatives for Urban Agriculture in Pesantren Sunan Gunung Jati Al Ba'alawy

\subsection{Discussion}

Some studies show that one of the reasons for promoting UA is for sustainability, particularly to reduce poverty, diversification of livelihoods, income-generating, and as markets where UA producers are also consumers [2-4,6]. However, reflecting on the initiative of UA in Semarang, to improve the community capacity by income generating especially making UA as a livelihood is still challenging to achieve. The condition is in contrast to the implementation of UA in developed countries that have started to make UA as one of their lifestyles or livelihood. This occurs since the implementation of UA in different regions depends on the socio-economic profile of the actors involved, thus the implementation of UA is accommodated to the collective and individual needs [7]. Therefore, marginalized social groups will perform UA for livelihoods, whereas wealthy social groups perform UA for recreational, leisure, and greening their surroundings [11]. However, UA activities in Semarang is more common in middle-income communities. Thus, it does not become their main livelihood, people still think they need permanent jobs and fixed income since UA has not been able to offer that.

Nevertheless, communities continue to do UA for leisure, and harvested crops can be utilized for personal consumption. It is different from the UA activities that are managed by 
individuals such as Crispy Farm which from the beginning has been market-oriented. These individuals make urban agriculture as a livelihood and not only produce for their consumption but also for sale.

Although UA has not been able to guarantee an excellent financial condition for some communities, initiatives of UA through the yard optimization program and the establishment of KWT and KT has been able to realize an excellent social cohesion and community participation. Communities have a legal institution to gather and share experiences related to UA in their neighborhood. UA also become a social innovation that creates different opportunities from the endeavor. UA provides neighborhood garden is not only an urban environment but also the perfect concept that must meet social needs, develop social relationships and form new collaborations [12].

Thus, the UA must emerge from an understanding of the social groups involved, the institutions that create their environment, and the space in which they are lived. As an innovative approach, UA must continue to evolve. Moreover, UA is a process that should not end with the creation of an urban garden but should continue to grow as needed, while its effects and impacts are monitored. The success of UA implementation can be improved, so there is an opportunity to scale up and increase the number of beneficiaries. The vision of UA implementation can arise, not only a vision for doing UA activity but also changes in social structure for the benefit of marginalized social groups [12]. Changes to social gatherings in UA Communities can be seen in Figure 7.
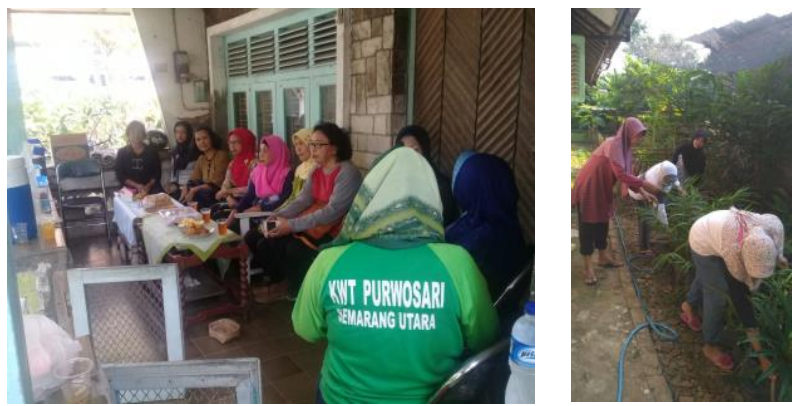

Fig 7. Social Gathering of UA Communities

UA has a positive impact on the environment as it improves air absorption by greening urban environments while increasing recycling potential by reducing the volume of organic food waste through compost [13]. Utilization of used bottles and plastic waste as a planting medium also helps reduce plastic waste. UA offers the potential for a win-win solution where the major urban management problems that are waste disposal can be handled at the same time as increasing food security through the optimizing waste [14]. Figure 8 shows that waste can be used as a planting medium in UA activities.
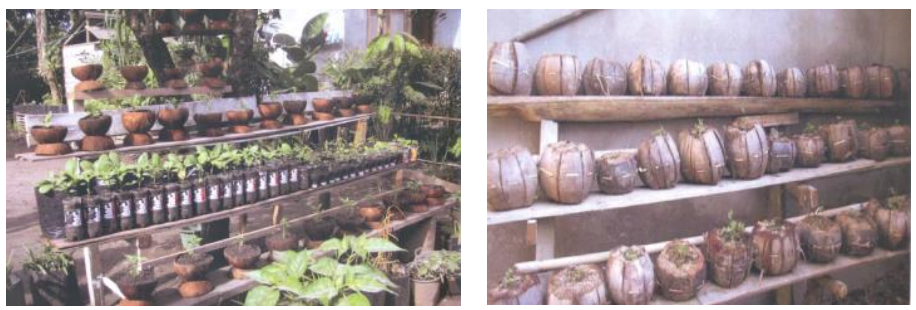

Fig 8. Utilization of waste as a planting medium 


\section{Conclusion}

The initiation which is conducted by the government, community/individual, university, and corporation to initiate UA activities have different results in communities. Regarding initiative of urban agriculture to the pathways for sustainability, can be concluded that initiatives from individual, communities, university, and corporation are more promising to promote sustainability rather than initiatives which comes from the government. There is a difference between initiation by the government and those initiated by individuals or communities. Initiation by the government has not been able to guarantee sustainability, especially from the economic aspect. Most people who get initiation from the government are doing UA as an activity to fill their spare time.

Nevertheless, initiation by the government can increase the participation of the community especially with the establishment of KWT and KT followed by the yard optimization program. The existence of the KWT and KT ensures that UA has the opportunity to continue to grow as a forum for communication of communities.

In contrast, initiations by communities, individuals, universities, and companies promise different things. High interest in UA activities and economic benefit become central point to the initiation of individuals/communities, thus making UA as part of their livelihood. Meanwhile, initiatives from universities and companies are more focused on providing goods and services such as sharing knowledge and technology. The major difference among initiatives is due to community eagerness to do UA activities if it comes from their interests and desires, whereas initiatives from the government are more likely to encourage community participation and as part of social innovation.

\section{References}

1. Game I, Primus R. Urban Agriculture [Internet]. GSDR 2015 Brief. 2015. Available from: https://sustainabledevelopment.un.org/content/documents/5764Urban Agriculture.pdf

2. Redwood M. Urban agriculture in urban planning: generating livelihoods and food security. Redwood M, editor. London, United Kingdom: Earthscan and the International Development Research Centre (IDRC);

3. Slabinki JM. From wasteland to oasis: How Pennsylvania can appropriate vacant urban land into functional space via urban farming. Widener Law J. 2013;22:253-87.

4. Zezza A, Tasciotti L. Urban agriculture, poverty, and food security: Empirical evidence from a sample of developing countries. Food Policy [Internet]. 2010;35(4):265-73. Available from: http://dx.doi.org/10.1016/j.foodpol.2010.04.007

5. 100 Resilient Cities. Resilient Semarang - Moving together towards a resilient Semarang. First Edit. Semarang: Semarang City Government; 2016. 168 p.

6. Cahya DL. Analysis of urban agriculture sustainability in Metropolitan Jakarta (case study: urban agriculture in Duri Kosambi). Procedia - Soc Behav Sci [Internet]. 2016;227(November 2015):95-100. Available from: http://linkinghub.elsevier.com/retrieve/pii/S1877042816307339

7. De Bon H, Parrot L, Moustier P. Sustainable urban agriculture in developing countries . A review. Agron Sustain Dev. 2010;30:21-32.

8. Miles MB, Huberman MA, Saldaña J. Qualitative data analysis: A methods sourcebook. Third. Oaks,CA: Sage; 2014.

9. Tamara AP, Rahdriawan M. Kajian pelaksanaan konsep kampung tematik di kampung hidroponik Kelurahan Tanjung Mas Kota Semarang. J Wil dan Lingkung. 2018;6(1):40-57. 
10. Sejati AW, Buchori I, Rudiarto I. The impact of urbanization to forest degradation in Metropolitan Semarang: A preliminary study. IOP Conf Ser Earth Environ Sci. 2018;123(1).

11. Kontothanasis G. Social practices of urban agriculture in the Metropolitan Region of Thessaloniki. Procedia Environ Sci [Internet]. 2017;38:666-73. Available from: http://linkinghub.elsevier.com/retrieve/pii/S1878029617301585

12. Buić M, Cunk K, Kozina J, Kumer P. Approaching urban agriculture as a social innovation: Guidelines for the development and implementation of an action plan [Internet]. $2017 . \quad$ Available from: http://www.ifuplan.de/images/ifuplan/projekte/raumentwicklung/17801_agrigo4cities/ Agrigo4cities_Guidelines.pdf

13. Ackerman K, Conard M, Culligan P, Plunz R, Sutto M-P, Whittinghill L. Sustainable food systems for future cities: The potential of urban agriculture. Econ Soc Rev (Irel). 2014;45(2):189-206.

14. Drechsel P, Kunze. Waste composting for urban and peri-urban agriculture: closing the rural-urban nutrient cycle in sub-Saharan Africa. New York: CABI Publishing; 2001 . 